This item was submitted to Loughborough's Research Repository by the author.

Items in Figshare are protected by copyright, with all rights reserved, unless otherwise indicated.

\title{
Rethinking the employment relationship: a neo-pluralist critique of British industrial relations orthodoxy
}

PLEASE CITE THE PUBLISHED VERSION

http://dx.doi.org/10.1080/09585192.2012.667429

PUBLISHER

(c) Taylor \& Francis

VERSION

SMUR (Submitted Manuscript Under Review)

LICENCE

CC BY-NC-ND 4.0

REPOSITORY RECORD

Ackers, Peter. 2019. "Rethinking the Employment Relationship: A Neo-pluralist Critique of British Industrial Relations Orthodoxy”. figshare. https://hdl.handle.net/2134/15012. 
This item was submitted to Loughborough's Institutional Repository (https://dspace.lboro.ac.uk/) by the author and is made available under the following Creative Commons Licence conditions.

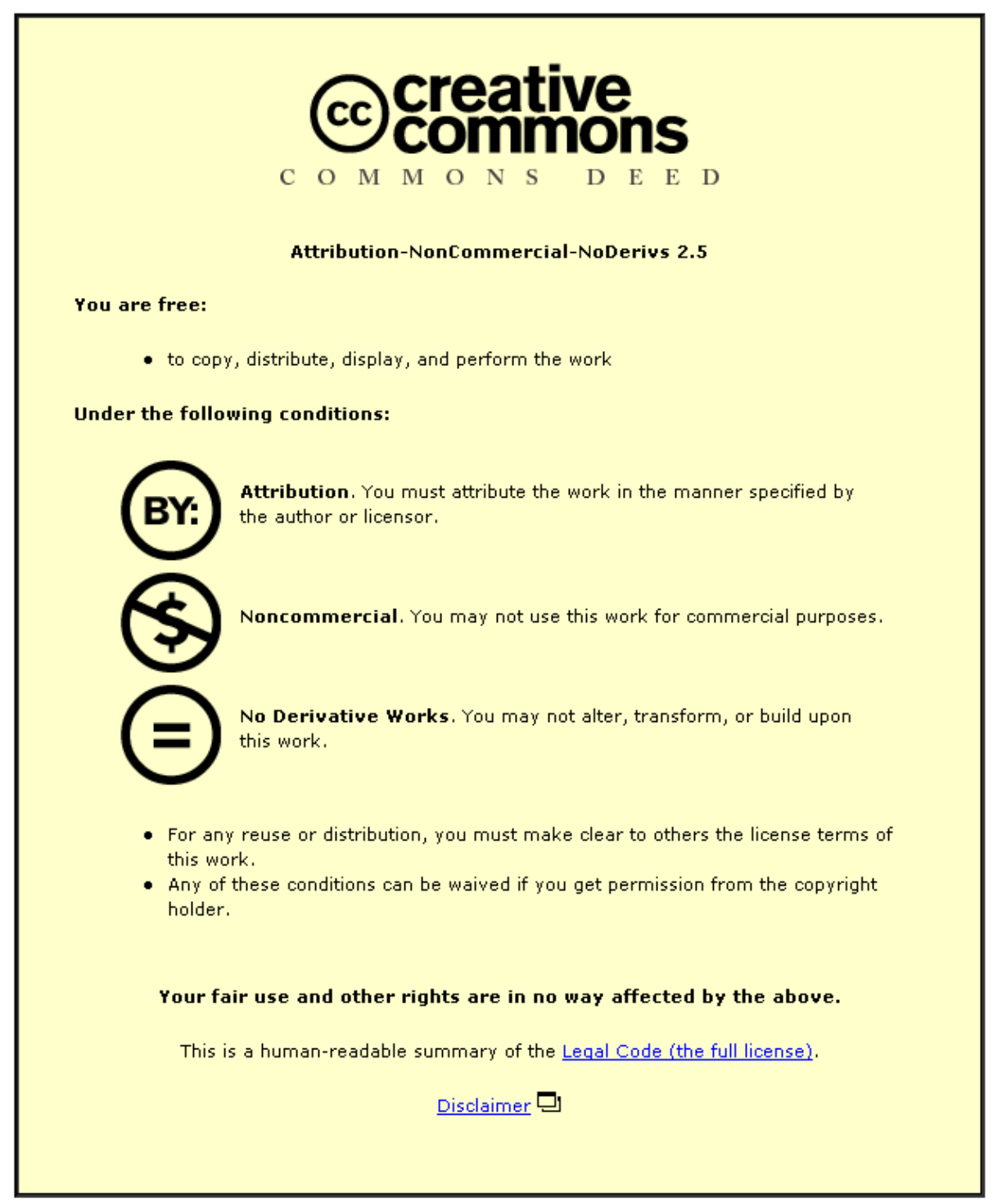

For the full text of this licence, please go to: http://creativecommons.org/licenses/by-nc-nd/2.5/ 


\title{
Rethinking the Employment Relationship: A neo-pluralist critique of British Industrial Relations orthodoxy ${ }^{1}$
}

\section{Peter Ackers ${ }^{*}$}

\begin{abstract}
Radical-pluralism, the mainstream perspective for British and European Industrial Relations, centres on a Marxian, sociological conception of the employment relationship, which structures explanations of power and conflict. This theoretical critique stresses the historical specificity of the experience of work and the explanatory limitations of the employment relationship. The intellectual history of radical-pluralism is traced from Fox (1974) to Edwards (2003) and Blyton and Turnbull (2004). Five objections to the radicalpluralist employment relationship are outlined and an alternative, neo-pluralist sociological and historical perspective is sketched.
\end{abstract}

Keywords Industrial Relations, Employment Relationship, Pluralist, Radical, Unitarist, Sociology, History, Theory

\section{Introduction: A new conventional wisdom}

Since the pluralist ethic does not postulate a balance of power, a demonstration that this balance is an illusion does no damage to pluralism, but Fox's exposition of the radical perspective is nevertheless worthy of attention for its own sake. Most of it is conducted at a highly abstract level, using terms such as 'capital' and 'labour'. To assess and measure the power of these two - if indeed we could be clear what they are - is even more difficult than measuring bargaining power in any specific industrial situation. So how could any argument over the existence of a balance be settled? But his exposition makes little or no use of empirical evidence. It is a matter of exploring definitions (Clegg, 1975: 315).

Over the past two decades the employment relationship has become the master concept of a British ‘Industrial Relations Perspective’ on contemporary employment and management (Colling and Terry, 2010: 7; Sisson, 2009). In the battle of ideas around HRM, this perspective offers a theoretical alternative to more managerial and individualistic pretenders like 'the psychological contract' or 'employee engagement'. ${ }^{2}$ Within the British Industrial Relations (IR) tradition, this represents the triumph of a particular sociological mode of analysis, driven largely by what I will term after Batstone (1984), radical-pluralist IR academics, such as Alan Fox (1974),

\footnotetext{
* Peter Ackers, School of Business and Economics, Loughborough University, Leicestershire, LE11 3TU, UK (e-mail: P.Ackers@lboro.ac.uk).
} 
Paul Edwards (1995, 2003) and Paul Blyton and Peter Turnbull (1994, 1998, 2004). The new IR conventional wisdom has largely displaced an older, more polarised debate between Marxists like Vic Allen (1966) or Richard Hyman (1975) and pluralists, such as Allan Flanders (1975) and Hugh Clegg (1979).

As I have argued elsewhere, this ‘sociological turn’ has played a crucial part in regenerating the British IR academic tradition and fostering a distinctive, critical take on HRM as a counter point to more unitarist, managerial accounts; an achievement with global resonance (Ackers, 2011a). The concept of the employment relationship is indeed central to this intellectual project and invaluable both as an ideal type doorway to critical, empirical employment research and as a normative vision of the place of work in society. However, the employment relationship can also become an overextended, loaded and 'lazy' concept, which carries over unexamined assumptions from Marxist social philosophy into social science analysis and thus restricts unduly the available public policy options. In particular, though the radical-pluralist version claims to entertain both conflict and co-operation at work, it carries a default bias in favour of the former; going beyond what is justified by a more balanced and openended neo-pluralism. Hence my critique is both ideological and methodological: for this new IR conventional wisdom claims structural insights into the fundamental nature of power and conflict for all paid work, when such issues can only be explored by empirical research into local context and institutions

Criticisms of structural sociological claims are not new to the study of employment or Labour History; nor are they confined to any single ideological wing of academia. As the Marxist historian, EP Thompson (1976: 387) once commented: 
Sociologists complain, at times, that social historians are insufficiently self-conscious as to their own conceptualization, and that they tend to offer their findings as particular findings, relevant only to their particular context, and are excessively cautious in making extended generalization. And social historians, of course, offer exactly the converse criticism: they sometimes find that sociologists are over-anxious to derive from particular evidence generalizations and typologies which are then translated to inappropriate contexts.

In other words, sociologists tend to over-extend theoretical explanations, using concepts and models where only empirical research will do the job. As we saw in the opening quote, this reservation also surfaces in Clegg's (1975) critique of Fox's (1974) radical-pluralist sociology. He objects not just to Fox’s Marxian ideological conclusions about power and conflict, but also to the intellectual method by which he reaches these. This reflects a strong and persistent, historical institutionalist suspicion of abstract sociological or economic models. Thus Clegg's much earlier criticism of HA Turner’s classic study of the cotton unions, shares Thompson’s historical reservations.

He is determined that his categories shall fit all instances, and provide the solution for every problem...The attempt to apply functional categories drawn from the cotton industry to geographical differences in mining seems to me to illuminate nothing and to obscure a good deal (Clegg 1963: 227).

In the same way, the concept of the employment relationship has grave explanatory limitations when we come to consider real workplace situations in their full natural context. All the writers discussed below are aware of this issue. Fox $(1958,1983)$ began and ended as a historian and a historical sensibility runs through all of his work. Edwards' (1995, 2003) full synthesis of pluralist and radical perspectives is hedged in qualifications about institutions and context, and immediately followed by Hyman on ‘The Historical Evolution of British Industrial Relations'. Likewise, Blyton and Turnbull’s (2004: 36-48) 'dynamic context' is hot-on-the heels of their 'theory of employee relations', with 'varieties of capitalism' sandwiched in between. The 
empirical analysis of these authors is replete with institutional detail and, often, almost indistinguishable from standard pluralism. Yet theory does matter and all these writers claim radical insights into the structural nature of the employment relationship, which deliver a deeper understanding of power and conflict than that found in classical pluralism. And this begs the question of just how far the abstract concept of the employment relationship can take us in understanding what happens in real flesh-and-blood historical workplaces; and at what point do historicalinstitutional explanations kick in?

There are two quite distinct and logically unrelated social science fractures here, as the equivocal position of EP Thompson demonstrates. One is an ideological divide between pluralists and radicals, largely about the nature and extent of class conflict and power imbalance in society and work. The other is a methodological divide between theoretically ambitious social science explanation and a more historical or empirical approach. For simplicity I will characterise this second division as between structural sociology and historical institutionalism - both defined in the widest sense. Many academics in IR, HRM and the sociology of work slide across the two underlying fractures; others link them together. Thus Clegg combined ideological pluralism with a historical institutional method; a position I would like to resuscitate and develop. However, ever since the 1970s radicalisation of Alan Fox, the dominant IR version of the employment relationship has blended radical-pluralist ideology with a 'materialist' structural sociological method. The danger of this conjunction, in my view, is that a priori assumptions about power and conflict are smuggled into the generic employment relationship, shaping the social science analysis of real 
workplaces and limiting the public policy possibilities available for management, trade unions and the state.

It is not my intention here to address the entire Marxist and radical corpus of writing on IR, HRM and the sociology of work; a huge task. The focus is instead a much narrower one on the radical-pluralist tradition of IR writing, in so far as this incorporates claims about the fundamental structural character of the employment relationship. This is to trace selectively just one line of intellectual development by, in effect, reading backwards from the current mainstream radical-pluralist IR position. Hence I will not discuss the whole-hearted Marxist IR tradition of Allen (1966), Hyman (1975) and Kelly $(1988,1998)$ or the labour process tradition, even though both have influenced the arguments discussed here. Whereas political Marxism moves through three logical steps - (1) a critique of capitalist social relations, (2) a political strategy for the overthrow of these, and (3) an alternative Socialist system - radical pluralism tends to eschew the second and third, as early Marxist critics noted (see Wood and Elliot, 1977). ${ }^{3}$ We should note that this leaves a heavy silence over both the normative social philosophy underlying contemporary IR and the public policy solutions arising from it - which I return to in my conclusion.

The article runs as follows. Next, I chart and critique the rise of the concept of the employment relationship as the master concept of British IR, taking in the classical pluralist tradition of Clegg, Flanders and Fox, and then the radical-pluralist response from Fox, Edwards and Blyton and Turnbull. The following section adumbrates a series of 'limitations’ or objections to an over-extended, generic usage of the concept. 
Finally, I conclude by outlining an alternative five-fold, neo-pluralist reading of the employment relationship.

\section{Classical IR pluralism on the Employment Relationship}

So long as trade unions and collective bargaining were central institutions in British employment, the concept of the employment relationship occupied a less central place in academic thinking. Instead, other concepts, such as 'industrial democracy’ (Webb and Webb, 1897; Clegg, 1960) or 'industrial relations systems’ (Dunlop, 1958) took central stage. Besides, well-targeted institutional description and analysis often seemed enough. Hence, Flanders and Clegg's (1954: v.) foundation text, The System of Industrial Relations in Great Britain, declared:

The form of its contents requires little explanation. Trade unions and employers' associations are the chief institutions of industrial relations. Their main relationship is through collective bargaining.

But it would be quite wrong to see this early, narrowly institutional focus as the end of pluralist thinking on the employment relationship, as Blyton and Turnbull (1994: 23) tend to. A quarter of a century later, Clegg's Changing System (1979: 452) stated: 'There is no doubt that the employment relationship is central to industrial relations'. In between much groundwork had been done to elaborate a distinctively pluralist view of the workplace (see Edwards, 2003: 8).

Flanders' (1975: 86-9) celebrated 1965 essay, 'Industrial Relations: What is Wrong with the System?' contains a three-fold model of 'the employment aspect; the relations between enterprise and employees and among those employees themselves' within a broader theory of IR as 'rule-making' or the 'study of the institutions of joint regulation’. Flanders deliberately substitutes the last term for the Webbs’ (1897) 
narrow economic conception of 'collective bargaining' (addressed directly in the 1968 essay; 'Collective Bargaining: A Theoretical Analysis'). According to his new scheme, procedural rules regulate 'collective relations' between 'representative organisations', such as trade unions and employers associations; while substantive rules regulate wages and conditions, or market relations and managerial relations, directly between employers and employees. As Flanders (1975: 88) observes, the latter are authority or power relations:

Whatever its precise terms, and whether they are expressly stated or implied, the contract is always, in its economic substance as distinct from its legal form, a wagework bargain...once there is a contract the employee on the job enters another set of relationships...In the broadest sense of the word these relationships are political, not economic. We may refer to them as managerial relations because they arise out of the organisation of management, which has the task of governing the enterprise in order to further its objectives.

Moreover, the informal workgroup challenges this management authority by methods such as restriction of output, creating a third category, human relations, or 'organised group relations' and making the 'business enterprise....at once an economic, a political and a social institution'.

A number of features stand out here. First, the three dimensions of the employment relationship operate between different groups of employees as well as between these groups and the employer - something lost in later, manichean radical-pluralist formulations. Second, the theory links ‘internal and external job regulation’ (Flanders 1975: 90), while addressing relations between groups of workers and management within the business organisation. Third, issues of power and conflict are explicitly addressed without predetermining the balance of power or the level of conflict. The only presumption is that normally this tension can be managed by negotiation between management and groups of employees. In the 1968 essay, 'Collective 
Bargaining: From Donovan to Durkheim', Fox and Flanders furnish a theoreticallyinformed social science strategy - building on the 1968 Donovan Royal Commission report on Trade Unions and Employers Associations - to address the problems of unofficial strikes, labour inflexibility and inflation. 'Reconstruction of Normative Order’ (Flanders, 1975: 267) required a reconfiguration of institutions and relationships in all parts of the voluntary national IR system, centred on national tripartite Incomes Policy and workplace 'productivity bargaining', with roles for the state, employers, trade unions and workgroup representatives.

Fox’s (1966: 399, 393-4, 398) Donovan paper on IR ‘frames of reference’ builds an explicit sociological base for this pluralist diagnosis. Above all, he sets out to scotch the unitarist perspective that employers and employee share the same interests and values; a view which Flanders and Clegg (1954) had earlier associated with Human Relations. Accordingly: ‘conflict is endemic to industrial organization', which 'is made up of sectional groups with divergent interests'.

Industrial government cannot claim the right to unconditional allegiance, for its diverse responsibilities sometimes oblige it to act against the interests of its members as they see them. Potential disaffection is therefore implied by the very nature of the industrial organization.

One problem with this bi-polar presentation of pluralism, as the opposite of unitarism, is that it allows conflict to eclipse co-operation - as became apparent when a third, almost pure conflict model, New Left Marxism, appeared on the scene (see Hyman, 1975). In truth, IR pluralism is a conflict and co-operation theory. Hence, Flanders' public-policy orientated pluralist IR theory, animated by ethical socialist ideals, was expressly directed at producing higher levels of compromise, partnership and cooperation in the workplace, while respecting the distinctive role of management and trade unions (see Kelly, 2010). But Fox also added something else to the pluralist 
sociology of the workplace, which expanded its range. Whereas Flanders (1975: 86) had effectively ruled individual or 'unstructured' relationships as outside the purview of the employment relations system, Fox's discussion of organized and unorganized conflict brought them back in again.

So long before Clegg adopted the term, British pluralists had developed a concept of the employment relationship that was multi-faceted, sociologically credible (though underdeveloped) and parsimonious in the a priori claims it made on workplace realities. Nor were they naïve about contemporary society, in the way that radicals have suggested. As Batstone (1984: 21) argues:

it is not the case that the liberal pluralists assume an equality of power in society: it would be more accurate to say that, broadly speaking, they would prefer to see the continuation of the existing structure of inequality than to embark upon moves to greater inequality which they fear might end up in dictatorship and poverty.

Clegg and Flanders had reached this judgement by the 1950s, after a close examination of the totalitarian Communist and Fascist experience, and as part of the social democratic vision for post-war reconstruction.

\section{Fox's Beyond Contract and the roots of the radical-pluralist view (1974)}

Later, discussing Marx, I identify myself (p.220), with the view that at the heart of the employer-worker relationship lies 'the massive asymmetry of reciprocity which spells exploitation', with the employer appropriating 'the maximum discretion in making decisions about the goals and methods of the productive process, the disposal of the product, and the behaviour and rewards of the participants' etc.

This is how Fox (1979: 106) defends ‘the central analytical framework’ of Beyond Contract. The book claims to 'examine this employment relationship more closely in the context of the contractual society that had emerged' with industrialisation (Fox, 1974: 176). And Fox introduces a radical-pluralist version of the employment relationship that is both infused by a Marxian conception of the fundamental power 
conflict between capital and labour and fully elaborated in sociological terms that transcend both Marxism and pluralism. Much of his analysis is couched with historical examples and explained through the writing of Weber, Durkheim and others, as well as Marx. Indeed, at one point he takes a divergent radical Weberian road, finding the roots of oppression in a combination of power and bureaucratic rationalisation, rather than simply private property (see Fox, 1974: 228-9). This said, the socialist panacea of public ownership remains a necessary if not sufficient condition for a future high-discretion, high-trust employment world, where pluralist values can become a social reality (Fox, 1979: 107). And Fox assimilates Durkheim into his radical argument only by characterising modern society as a 'forced division of labour' of grossly unequal exchange, rather than following the more obvious pluralist emphasis on organic solidarity between professional associations (Fox, 1974: 229-236).

Fox's central argument is as follows. In 1970s industrial society most workers are in low discretion jobs as a result of the division of labour. Modernity saw the replacement of the old diffuse, personal 'status' contract between people with the narrower 'purposive’ market contract (Fox, 1974:153). However, once inside the workplace, the problem of management control arose and, during the nineteenth century, the traditional master-servant relationship was assimilated into the nominally liberal contract of employment. These factors made the employment relationship an asymmetrical, low-trust one between power-holders and power-subjects. Thus, while Fox draws in elements of Weber's rationalization thesis and Durkheim's anomie, he guides these towards a fundamentally Marxian conclusion. A crucial turn in this argument comes when it is deployed as an explanation of the contemporary British 
employment problems of strikes, inflation and restrictive practices. Pluralist solutions such as Incomes Policy and productivity bargaining are now rejected because they do not address the fundamental low-trust dynamic of modern industrial society. Indeed, pluralism becomes an ideology of ‘enlightened managerialism’, while Fox (1973: 212) tends to conflate management of all stripes with capitalist power holders. Unless there is some socialist transcendence - about which Fox (1974: 356-361) is extremely vague while rejecting the more revolutionary options - these problems will simply get worse.

This rationale for a fully developed sociological theory of the employment relationship is echoed in a more muted version by current radical-pluralist IR writers. 'Pluralism offers no comprehensive explanations for such conflicts, beyond acknowledging that different interests prevail in the workplace', argue Blyton and Turnbull (2004: 32-3); while Edwards (1995:10) refers to pluralist 'institutional tinkering' and an associated failure 'to acknowledge that “disorder” ran much deeper than a weakness of institutions'. The larger claim, taken from Fox and shared by these authors - who tend to cross-fertilise their case - is that the radical insight into the nature of the employment relationship can furnish fundamental explanations of 'the structural bases of conflict' (or presumably its absence) anywhere in the modern world (Blyton and Turnbull, 1994: 28; see also Gabriel, 1983, Phillips, 2007). There is one crucial difference, however. While Fox retained some socialist vision of a postcapitalist society where such fundamental conflict no longer exists and high-trust relations are possible, this dimension disappears from Edwards (1995) and Blyton and Turnbull (1994). Only social science analysis is left. 
But, for our purposes, it is most remarkable that Fox attempts to explain the British, national IR problem of the 1970s - a very specific institutional context - using generic sociological theories about capitalist and industrial society. As Fox (1974: 167) himself notes: 'Models always carry the danger, however, of being mistaken for descriptions'. This is precisely what happens in Beyond Contract (1974), as an allpurpose theory of the employment relationship brushes aside the national context of what Fox (1983) later termed, History and Heritage. Thus he conflates British and American pluralist IR writing, drawing the emphasis on an equal balance of power from the latter, ignoring the political and institutional difference between a British social democratic settlement of full employment, tripartite institutions, mixed economy and welfare state and the American relatively free market alternative (see Ackers 2005b). From this Olympian height, all ‘modern’ or 'western’ societies seem more or less the same, allowing Fox (1974: 275, 322) to comment that: 'This view of the American scene differs only in detail from other Western societies’; or, for 'Instability and Inflation...Britain’s experience can serve as an exemplar'. At the same time, for such a broad-ranging social theorist, Fox tends to treat the narrow employment system of trade unions and collective bargaining as if this constitutes the entire societal story as far as pluralism is concerned.

If Fox moves too easily across comparative space, the same can be said of historical time. The two added together do violence to context. In the latter case, Fox (1974: 356, 279, 286) takes classical sociological arguments and legal ideas about contract and the master-servant relationship from nineteenth century capitalism and applies them to the 1970s, as if the post-war British 'social democratic settlement' was largely 'rhetoric' and had made only a 'marginal' difference to the essential capitalist 
employment relationship. By contrast, the classical British IR pluralism of Clegg and Flanders was not only infused with European social democratic values, but also grounded in real changes that had taken place in the nature of post-war society (see Ackers, 2011b). In Clegg’s words (1979: 455): 'The pluralist may prefer to talk of social democracies (where the term applies) rather than capitalist societies’ (my emphasis). Fox (1975: 242) is aware of the argument:

But what if the grosser inequalities of power were, as Durkheim suggested, being reduced by the growth of democratic values and institutions, both in the wider political order and in industry itself. A prima facie case could be made for this effect. To the extent that political parties representing working-class interests gained an effective foothold in democratic political systems they could hope for access to the levers of control. And within industry could it not be argued that through trade unionism, which redressed the balance of power, collective bargaining offered a means of eliminating unjust contracts?

However, like most radical writers of that era, he does not take seriously the reforms in British society and builds his critique around an essentialist Marxian sociology of power in all 'capitalist' societies. And by evading the European social democratic case, Fox merely attacks pluralist ideology in its weakest, narrowest sense as American enterprise bargaining. Overall, his volatile admixture of abstract sociology and historical institutional analysis loses sight of where one ends and the other begins.

Of course, there was a wider employment crisis of strikes and inflation across advanced industrial societies from the late 1960s, and certain common economic, social and political trends contributed to this (see Crouch and Pizzorno, 1968). This does not entail, however, claiming that a single cause can be found in the static reality of the low-discretion, low-trust employment relationship or that national institutions were not influential. Reynaud (1980: 9) contends that shifting 'power relations between groups' should be 'established a posteriori rather than predicted on objective a priori grounds'. And Fox's generic analysis of trust and the inflation crisis also fails 
to explain why some European capitalist societies, notably Sweden and West Germany, were much more successful than Britain in building high-trust relations during the post-war period and recovered from the employment crisis much more quickly and completely; or why others, such as Ireland and Australia, managed to reform their systems and 'restore order' in ways very similar to those envisaged by British pluralists. For all its rich insights, Fox's study is a classic instance of how an over-extended, schematic use of a Marxian assymetrical employment relationship conceals more than it reveals. As Clegg remarks in the opening quote, sociological abstractions cannot explain complex, historical institutional realities.

\section{Paul Edwards (1995 and 2003) and the new radical-pluralist orthodoxy}

The radical-pluralist concept of the employment relationship became IR orthodoxy with the almost simultaneous publication of two outstanding, authoritative textbooks that defined the British field for a decade or more: Blyton and Turnbull (1994), The Dynamics of Employee Relations and Edwards (1995), Industrial Relations. Edwards continued an Oxford/Warwick tradition of pivotal IR texts, running from Flanders and Clegg (1954), through Clegg $(1970,1979)$ to Bain (1983). In the last of these, Peter Nolan’s chapter on ‘The Firm and Labour Market Behaviour’ had laid another Marxian economic plank, with its critique of neo-classical economics and distinction between labour and labour power. It was Edwards’ (1995, 2003; see Ackers, 2004) sociological account, however, that placed the radical-pluralist synthesis at the heart of Warwick IR orthodoxy, where it remains (see Colling and Terry, 2010).

Edwards’ (1995: 5, 9) introduction, ‘The Employment Relationship’, declares: ‘The subject is thus about the ways in which the employment relationship is regulated'; a 
formulation that balances a core socio-economic relationship with 'rules of employment [that] are shaped by their legal, political, economic, social and historical context'. Accordingly: 'A proper understanding of the employment relationship thus needs to be multi-disciplinary'. The decline of trade unions and extension of management regulation mean that 'a focus on collective bargaining no longer captured the key issues of the regulation of the employment relationship’. To begin with, 'the labour contract is indeterminant' or open-ended; in other words, it is something that employers and workers must negotiate on a daily basis, either collectively or individually. Moreover, it balances 'cooperation and conflict' and 'no serious discussion would deny that there can be shared interests'. Here Edwards (1995: 13) moves forward cautiously, suggesting that 'product market circumstances' and 'macroeconomic circumstances' both shape labour management policies. All this is quite consistent with the classical pluralist account.

But Edwards (1995: 15-16) then reveals a Marxian sociological view of 'the fundamental nature of the employment relationship', which develops Fox's earlier analysis. It is not enough, he argues, to merely acknowledge both conflict and cooperation; the real question is whether conflict is 'more basic'? In his view, it is.

The key point about the indeterminancy of the labour contract and strategies of labour control is that managers and workers are locked into a relationship that is contradictory and antagonistic. It is contradictory not in the sense of logical incompatibility but because managements have to pursue the objectives of control and releasing creativity, both of which are inherent in the relationship with workers and call for different approaches. The relationship is antagonistic because managerial strategies are about the deployment of workers' labour power in ways which permit the generation of a surplus.

This ‘structured antagonism’ underlies and belies any everyday evidence of cooperation, but is not founded on a simple conflict of interest between capital and labour (as in orthodox Marxism), since workers’ interests are potentially manifold. It 
does rest, however, on the employer's need to extract a surplus from employees, by balancing management strategies of control and commitment. In a strange sense, employees may benefit from this efficient extraction, since it secures their employment prospects, even though 'this should not disguise the fact that they are exploited'.

On closer inspection, there are some interesting hints and silences in Edwards' new definition. While he deploys the Marxian language of 'capital', 'labour', 'workers' and 'exploitation' and describes ‘the relationship (as)...one of conflict, power and inequality’ (Edwards, 2003: 27), there is no specific discussion of power asymmetry in the employment relationship. Indeed, the rather over-heated term, structured antagonism, applies as much to the relations between David Beckham and LA Galaxy, as it does to Indian factory workers. Even so, when Edwards (2003: 13) declares that, 'an appropriately explicated radical view is in my view analytically the best means to understand the nature of the employment relationship', this does create a general expectation that conflict will prove more profound that co-operation - which is always working against the sociological grain.

Arguably, Edwards' definition does too little for radicals and too much for pluralists the dilemma of radical-pluralism. In the first case, without having something to say about societal class power (as orthodox Marxists have), it is unclear what makes his version more sociologically 'fundamental' than the basic pluralist sociological insight about conflict between interest groups. Indeed, he describes the primary sociological relationship in such general terms that both millionaire footballers and the wretched of the earth can be termed 'exploited'. For practical IR pluralists, Edwards' analysis may 
seem unproblematic if slightly otiose. As Clegg (1979: 452) once laconically observed, 'Both Marxists and pluralist are concerned with conflict, and both are concerned with stability'. In his view, theory didn’t make much difference to empirical social science. So a statement like: 'Management in short, is not only a continuous, active and uncertain process but also necessarily involves the balancing of forces which are pushing in opposite directions’ (Edwards, 2003: 16), sounds like an IR commonplace.

However, my central argument is that theory does make a difference to both empirical analysis and public policy. And for all the subtlety of Edwards' 'context sensitive' recent work, the notion of a structured antagonism does narrow the frame of IR research. So, in a recent Belanger and Edwards ( 2007) analytical framework, longterm 'compromise' between management and workers becomes a fairly exceptional state, produced by a unique constellation of technological, product market and institutional factors. And even where Edwards' own applied work is more open to local agency and choice (Ram and Edwards, 2010; Edwards and Sengupta, 2010), others have used his conception of the employment relationship as a fairly blunt instrument (see Ackers, 2012). The underlying problem is that Edwards (1995, 2003) goes beyond simply identifying a potential tension between management and employee (see also Blyton and Turnbull, 1994: 4), to load the employment relationship with an expectation that conflict is somehow normal and co-operation deviant - turning upside down most commonsense experience of work. At the same time, he understates the forces pushing for co-operation and ignores the tensions between groups of employees. 


\section{Blyton and Turnbull, The Dynamics of Employee Relations (1994, 1998, 2004)}

Blyton and Turnbull offer the most ambitious case for a radical-pluralist concept of the employment relationship, rooted in Marxian historical materialism. As their latest edition argues (Blyton and Turnbull 2004: 38-39; see Ackers 2005a):

To focus on the employment relationship has the advantage of homing-in on the (material) basis of the interaction between employer and employee, and the relationship from which all other aspects of employee relations stem. As already noted, to focus on a system of rules or the institutions of job regulation is to ignore the foundations underpinning such rules and regulation in the sphere of production, to run before learning to walk (and without an adequate map of which direction to run).

Their answer is that at 'its most basic level, every employment relationship is' both an ‘economic exchange' and a 'power relationship' between two parties, employers and employees. Because the exchange of labour power is different to any other commodity, the employment relationship is a continuous, open-ended authority relationship. The two sides are interdependent and display patterns of conflict and accommodation, 'but the employer is in possession of greater power resources than the employee, creating an assymetrical relationship between the parties'.

Blyton and Turnbull's (2004: 34, 13) theoretical framework is boldly structuralist and materialist. They endorse both Marx's view that 'the material productive base of society will shape political institutions, legislation, modes of thought, even the nature of the family' and a 'structure-driven' rather than 'event-driven' approach to history.

As a result:

The activities of institutions, such as collective bargaining or other 'rule-making processes', in fact arise from the employment relationship and cannot be understood in isolation from it. Thus trade union activity, first and foremost, is the organised expression of the grievances, deprivations and wider interests of employees that arise from their (subordinate) role in the process of good production or service provision... These activities can be grounded in a theory of the employment relationship (Blyton and Turnbull, 2004: 41-2). 
In other words, the core sociological concept of the employment relationship constitutes employee relations and only afterwards is the workplace 'also influenced by the wider society’. Like all perceptive writers on this subject, Blyton and Turnbull, 2004: 43, 36) are at pains to avoid the charge of determinism that such claims entail, pointing to 'the many and varied employment relationships that we observe in the real world' and the 'dialectic' that links material base and institutional superstructure. They agree that: 'it is conceptually inappropriate to draw conclusions about the subjective experience of work from arguments about the objective nature of labour in capitalism’ - quoting Korczynski (2002:155) - while still wishing to pre-determine the pattern of agents and relationships which shape these experiences. And while subsequent, substantive chapters embrace the institutional complexity of British IR, this doesn't make Marxian structural materialism and pluralist institutionalism easy bedfellows. Nor do these ostensibly arcane theoretical positions lead to 'much the same position at end of the day' (Clegg, 1979: 452). To advocate structure and then embrace complexity is to have your cake and eat it, and for social science analysis and public policy it matters which road you take.

Blyton and Turnbull's own trade union example is a good illustration of this. If the capitalist employment relationship per se is expected to throw up unions, a number of pressing questions become hard to answer. We might expect some local variation shaped by national institutional context, but why is this so great? And why are unions of any sort virtually absent from large parts of the historical past or the current developing world; and why are they declining dramatically in the post-industrial economies of the West? Very early on in this discussion we reach for influences outside the employment relationship. As Reynaud (1980:10) argues, organizations 
and institutions 'create a collective interest' - while, of course, individuals must first create them - and it was this construction of new collective identities that fired the 1970s employment crisis. 'These propositions are self-evident but they are often forgotten and classes or groups are spoken of as if they were direct social actors, while in fact the social actors are the organisations'. Simms and Charlwood (2010: 126) seem to concur: 'the collective interests of workers that are given voice by trade unions are a social construct’.

The sheer diversity of 'unions' suggests more than merely variations on a materialist theme. Hyman’s (2001) study of European trade unions identifies several contrasting traditions. Moreover, whereas British unions emerged very early, long before the Labour Party, most continental unions were established by socialist or communist parties, as ideas shaped the organisation of labour. So different are the many varieties of trade unionism that - but for the influence of institutional isomorphism (the spread of British models or socialist ideas) - we might be talking about entirely different organizations with little in common. When Durkheim advocates occupational associations and rejects French 'syndicats' he is discussing two very different types of bodies that both could be described as unions (see Fox, 1974: 236). The white collar professional bodies that now dominate the British TUC were barely regarded as 'unions' in the 1960s, when manual organisations predominated (see Blackburn, 1967).

The employment relationship is part of the union story, of course. The experience of working together for someone creates some potential tension and some predilection for collective identity of some sort. But as we now know, looking back from the end 
of traditional 'industrial' Labour History in the West and forward to an uncertain employment future, it doesn’t necessarily or even ‘usually’ (Blyton and Turnbull, 1994: 4) spawn unions, let alone strikes. If we want to understand the formation of unions from where we stand now, a more likely conclusion would be that certain very specific industrial conditions, such as coal mines and large factories, encouraged collectivism while ideas and institutions did the rest. Once you have an idea of a craft or a profession or of socialism the employment relationship starts to look very different. In short, Blyton and Turnbull too have claimed far more for the concept of the employment relationship than it can actually deliver in employment analysis.

\section{Five empirical objections to the radical-pluralist model}

The employer-employee or, as British law put it for so long, the master-servant relationship is one of acute imbalance. The employer possesses the economic power. The right of hire and fire, remuneration levels, working hours, work practices, indeed all facets of life at the workplace have been at the disposal and control of the employer in a society such as ours (Jenkins and Sherman, 1977: 1).

Thus opined the leader of the British white-collar and management trade union, ASTMS, at the height of 1970s trade union power: writing as if his relatively wellhealed members stood in the same shoes as the unskilled workers of Victorian England; as if full employment under welfare capitalism, professional credentials and changes in legal regulation stood for nothing. In this strong version of the radicalpluralist position, the employment relationship is something generic and permanently asymmetrical for all employees, that changes little over time or institutional context. The only counter to the powerlessness of the individual employee is collective trade union organisation and even this makes only a marginal difference. For many employees, in many different times and places, this generalisation works; but it fails as a general structural proposition about paid work due to five main objections. 
The first and most obvious is the trade cycle objection. Employee power in both market and managerial relations is enhanced by full employment and labour shortages. While, as Clegg (1975) argues, the absolute balance of power defies calculation, relative shifts in employment power are measurable by indicators such as strikes and wage rates. 'Power resources can shift over time', and Edwards (2003: 13) recognises the crucial influence of labour and product market environment on the experience of the employment relationship. Individual workers, work groups and trade unions all have more power during periods of full employment, like the long post-war boom. Employers are concerned not to lose skilled workers through labour turnover, when ample alternative employment exists, or production through strikes, when the can sell as much as they can make to an expanding market. In these circumstances, many groups of employees gain both strong bargaining power and the ability to exercise job controls. In short, the balance of power can shift, quite dramatically, towards or away from employers; and the experience of employment is quite different in periods of full employment, such as the Britain in the 1960s, compared to the same country in a period of mass unemployment, such as the early 1980s or today.

The second might be termed the neo-liberal objection, since writers such as Milton Friedman (1993), Robert Nozick (1974) and Frederick Von Hayek (1944), also have an economic, political and ethical understanding of the employment relationship that is as abstract and consistent in every way as the Marxian structural view. In simple terms, they see a free and equal contractual exchange between individuals. The IR conception has been constituted as a challenge to this neo-classical economic account 
of how market and managerial relations work. But, whereas classical pluralists, such as Clegg (1979), argue that the economic model fails to account for the complexity of empirical reality, radical-pluralists are prone to replace one abstract model with another. The neo-liberal unitarist model is not so much false as grossly oversimplistic. As a description of working life it presents a travesty of reality for low skilled workers in over-stocked mass labour markets, like modern India or the Victorian docks. Moreover, it tells us little about how labour is managed in the workplace. This said, the higher we move up the social structure, the closer the model comes to reality and the more out-of-focus the assymetrical view of 'wage labour' becomes. In contemporary Western society, there really are substantial groups of employees with significant individual bargaining power.

The professional society objection questions the underlying radical-pluralist assumption that power in contemporary society is fairly straightforwardly divided between capital and labour. The historian, Harold Perkins (1989), argues that while this may have been true for early twentieth century 'class society', we now live in a professional society, where private and public sector elites hold relatively privileged positions. Once we factor in house ownership, pension entitlements and associated share holdings, these employee groups also hold very considerable capital. In other words, while there are large inequalities of wealth and power in society, these do not correlate neatly with the two sides of the employment relationship; nor can we simply equate managers - many of whom work in the public sector - with capital. Contemporary professions, such as Doctors, protected by complex qualifications systems, are far from the undifferentiated 'workers’ of the Marxian employment relationship. Moreover, as Flanders (1975) argued earlier, many conflicts at work 
have always been 'demarcation disputes' between different employee status groups defending their interests against other employees.

All the above factors are shaped by the type of society we live in. The varieties of capitalism objection (Hall and Soskice 2001), applies across both time and space. As we have seen, the radical sociology of the 1970s was largely oblivious to any conceptual grey areas between pure ‘capitalism' and ‘socialism', such as social democracy; hence the broad-brush depiction of 'liberal-pluralists' (see Goldthorpe 1977, Wood and Elliott 1977, Fox 1979, Batstone 1984). The above quote from Jenkins and Sherman reflects that blind-spot. Today, by contrast, comparative institutional analysis, incorporating distinctive national state, labour and welfare traditions is central to British IR (see Colling and Terry 2010). 'The state influences the employment relationship', in Edwards's (2003: 10) words, and it 'can play a critical role in the character of market and managerial relations'.

Therefore, at one level of analysis, radical-pluralists recognise that the experience of employment can change quite dramatically as we move from co-ordinated to liberalmarket economies: whether from Britain today to Germany, or to Britain in the 1970s. Yet, at another level, they insist on a generic employment relationship characterised by inequality and conflict. IR theory must be able to integrate these two levels of analysis, by acknowledging that the employment relationship is more than just 'embedded' in a society (Blyton and Turnbull 2004: 44); it is actively constituted by national laws, institutions, values and norms. Seen in this light, a varieties of capitalism analysis is an opportunity to open up the full contextual complexity of employment at macro (state), meso (sectoral) and micro (company) levels. The danger 
is that it will be deployed to simply bolster the structural sociological claims, by bolting a deterministic, liberal-market stereotype of British employment onto the generic employment relationship.

Finally, there is the flexible labour market objection, which reflects changed labour market realities in Western economies over the past three decades and the very different patterns of work found in both early Western industrial society and the developing world today. IR as an academic field in the anglo-saxon world was very much a product of twentieth century mass production industrial society, in which a largely male, semi-skilled workforce developed a standard employment relationship linked to a breadwinner family role (Blyton and Turnbull 1994: 7-8). But, as we can now see, Fox (1974) was writing at the end of this industrial era. In a predominantly service economy, with a high proportion of part-time women and students, the expectations, orientations, and hence experience, of employees become much more diverse (Hakim 2000). In addition, the IR stress on the employment relationship as the primary tool for employment analysis is problematic in the developing world, where 'subaltern workers belong to households that combine several modes of labour' (van der Linden, 2010: 367; see Edwards 2003: 2). In India, for instance, over 90 per cent of workers are in the informal economy (see Bhattacherjee and Ackers, 2010).

Taken together, these five objections suggest that questions of power, conflict and collective behaviour at work are better explained by political and socio-economic context than by any essential features of the capitalist employment relationship. Yet two recent statements of IR orthodoxy take a stand on the assymetrical, predominantly conflictual, generic employment relationship. Thus for Keith Sisson 
(2009: 45) power, 'is unequally distributed between employer and employee’. And Trevor Colling and Mike Terry (2010: 8) opine, 'the employment relationship is unequal', adding that 'most workers have no choice but to engage in paid work and, in practice, many workers will have relatively limited choices between potential employers'. In the same book, Simms and Charlwood (2010: 124) 'take as our starting point that there is a fundamental imbalance of power in the employment relationship between employers and individual workers'. Once again, these abstract statements have real social science and public policy consequences, as in Terry’s (2010) subsequent scepticism about consultation or Simms and Charlwood's doubts about the viability of partnership between management and trade unions. Elsewhere, Hyman's (2005: 259, 255) pessimism about partnership is framed by observations that 'the relationship between employer and individual employee is essentially asymmetrical' and defines 'an ongoing relationship of (unequal) interdependence', wherein 'typically the area of conflicting interests remains predominant'.

Words like 'most', 'many' and 'typically' hint at a deeper complexity and raise the question of whether these are theoretical deductions or empirical generalizations. If the latter, we are entitled to know ‘where' and 'when'? Finally, as Clegg questioned at the outset, what does 'unequal' actually mean in relation to an employment relationship? What would an equal relationship between, say, a University lecturer and a University look like? Unless we make utopian assumptions about a low conflict alternative social system, characterised by equality of power, income and wealth - as political Marxists do - the question of employer/ employee power will always remain a complex and essentially relative one. In other words, it is only fruitful for social science to investigate the balance of power in relation to empirical comparisons with 
other real historical societies or situations, past and present. All large, complex human societies are highly unequal. The interesting problem for IR social science is to understand and explain changes in group power and behaviour across time and space and the public policies that influence this.

\section{Conclusion: A neo-pluralist alternative}

I have identified two central and related problems with the radical-pluralist concept of the employment relationship. One is the methodological problem of using an overelaborate structural generalization as either a substitute for empirical evidence or, more often, a distorting lens through which such evidence is gathered and assessed. The other, ideological problem is the Marxian emphasis on power-imbalance and its assumption that conflict will predominate over co-operation for all 'wage labour' Often a further direct link is made to workers' collective organization. ${ }^{4}$ Combined together, these theoretical assumptions stand in the way of a fully nuanced empirical analysis of employment in real societies and workplaces. In public policy terms, the all-purpose exploited 'worker' in the generic union also becomes a social science obstacle to realistically assessing the scope for strategies of workplace co-operation such as Partnership (see Johnstone, et al 2010). To conclude, I will sketch an alternative neo-pluralist (Ackers 2002, Kahn and Ackers 2004) understanding of the employment relationship, which suggests five solutions to these problems.

\section{(1) a Weberian ideal type}

Weber's alternative to Marxian structuralism sees sociological theory as the construction of ideal types or models that are not to be confused with empirical reality. As Thompson (1980:10) argues for 'class', the employment relationship does 
not exist in anything approaching its pure form in the real world: it is 'a relationship, and not a thing' ${ }^{5}$ Neither do 'capitalism' or 'the market', or other such abstractions (see Hyman 2005 for the latter). Thus in History and Social Theory, Peter Burke (1992: 28-32, 44-47) defines an ideal type or 'model' as: ‘an intellectual construct which simplifies reality in order to emphasize the recurrent, the general and the typical, which it presents in the form of clusters of traits or attributes'. He warns scholars against anachronism or, more broadly, carrying such concepts into new and inappropriate contexts and: 'Using models without admitting they are doing so or without being aware of their logical status.' Moreover, 'concepts are not neutral "tools". They tend to come in packages of assumptions which need to be scrutinized with care'. All these tests apply to the model of the employment relationship. So what generic traits can we retain from the current IR concept of the employment relationship? The short answer is: (1) an indeterminate character; (2) a potential for conflict or tension as well as co-operation; and (3) some tendency to collective behaviour. Everything else is institutional context. That is as far as we can go with a general model of the employer-employee relationship.

\section{2. a neo-pluralist expansion}

However, having subtracted loaded assumptions about inequality and conflict, we may enlarge the frame to take in other tensions, again without pre-judging outcomes. Still following the internal logic of the employment system, we may insist, with classical pluralism, that: (1) relations of conflict and co-operation also exist as tensions between employees. Demarcation disputes between trade unions were a major cause of strikes in the 1960s. 'Strategies of social closure' (Parkin, 1974) and ‘open’ and ‘closed’ models of union and professional organization (Turner, 1962) are 
enduring features of work; witness the National Health Service. Turning to external relations and tensions that, in an analytical sense, originate outside the employment system, there are: (2) the direct link between employees and customers in the service sector, again including relations of conflict and co-operation (Korczynski, 2002; Heery, 1993); and (3) the complex relations - part conflict, part integration, in no fixed measure - between work and family life, since 'workers' are rarely atomized individuals. Edwards (2003: 29) postulates a ‘semi-permeable membrane’ between work and society to preserve the autonomy of orthodox IR analysis. This should not imply, however, that either internal work relations are somehow more 'fundamental' or that those nominally 'external' will not predominate in many employment situations. That again is a question for empirical research.

\section{3. an historical institutional method}

The logic of my argument is that the best method of researching employment is the one that provides the strongest grasp of institutional context. As Burke (1992: 164) argues, 'historians, like ethnographers, offer reminders of the complexity and variety of human experience and institutions which theories inevitably simplify'. Hugh Clegg, the classical IR pluralist, is often regarded today as an unreflective empiricist or theoretical naïf whose ideas were overtaken by a more sophisticated social science. But social science does not 'progress' in some unproblematic way; and Norbert Elias has observed, 'the retreat of sociology into the present' (quoted Burke 1992: 12). There was method in Clegg's empiricism and as a trade union historian he was ever sensitive to 'complexity and variety'. The experience of work can only be comprehended by empirical research into the real-life institutions of society, including historical, case-study and ethnographic research. In an academic era of social science 
quantification, on the one hand, and abstract social theory, on the other, this view may be out-of-fashion, but it is not old-fashioned. Rather it is the enduring historical contribution to social science method.

\section{4. a constructive approach to public policy: partnership at work}

Classical British IR pluralism had strong public policy prescriptions for national employment problems: incomes policy, productivity bargaining and the broader reform of collective bargaining. These were directed at the state, unions and employers (see Flanders, 1964). Opportunities for such policy engagement are less today. This said, radical-pluralist pessimism about all forms of workplace cooperation has ham-strung the IR approach to HRM, even where openings do exist. One key instance is the Partnership debate. As we have seen, a rigid logic leads from unequal power to inevitable conflict to collective organization and back to unequal power, even where unions are strong and prepared to collaborate with employers. Determinist generalizations about the British neo-liberal variety of capitalism transmute this logic into an employment iron cage from which there is little hope of escape (Ackers 2012). Neo-pluralism moves beyond both classical and radical pluralism to bring co-operation back into the centre of the pluralist equation, allowing the scope for good employers and unions to construct shared values and interests. There is more sociological space for co-operation at work than the radical-pluralists would have us believe. This is not because simple unitarist solutions are available they are not - but because conflict and co-operation are 'indeterminate' and shaped by institutional context. People and politics can shape workplace institutions and relationships. 


\section{5. a normative vision}

Classical British IR pluralism tied together critical social science, public policy prescription and a broader underlying social philosophy of social democracy or ‘ethical socialism’ (Kelly 2010; Ackers 2011b). In its own way, IR Marxism operated across the same range. Radical-pluralism has settled for social science, squeezing out explicit normative statements about 'good' HRM. Strong assumptions about employers and unions lurk in the background and misleading management 'rhetoric' is ruthlessly exposed to evidence, but there is no counter vision. The triumph of neoclassical economic ideas reflects the current paucity of alternative ways of thinking about work and society. Neo-pluralism would make the employment relationship, in Durkheim's terms, a powerful normative concept, an ideal of how we would like to see working life organised in a sustainable, cohesive society (see Thompson 2004: 129-36; Budd, 2004). A more open-minded attitude to the prospects of workplace cooperation today would fuel a forward vision. This would highlight the ethical and social dimensions of a relatively long-term and continuous relationship, conducted face-to-face and by real people, living in local communities, and central to the life, livelihood and life-chances.

\footnotetext{
Notes

${ }^{1}$ I would like to thank Ed Heery, Marco Hauptmeier, Marek Korczynski, Nick Bacon, Stewart Johnstone and anonymous referees for their comments on my drafts.

${ }^{2}$ For reasons of clarity and style I have used 'IR' to refer to an academic paradigm and 'employment' to denote the subject of study or the actual behaviour of workers and managers. In British terms, there is an integrated academic field of IR and HRM. In global terms, it makes sense to see British IR as a particular school or approach to HRM.

${ }^{3}$ Nor do I discuss the radical-pluralist sociology of John Goldthorpe (1977), because, while he too charges IR pluralism with neglecting wider changes in societal structure and power, his critique does not rest on a Marxian structural account of the employment relationship.

${ }^{4}$ There is another weak link here: gross inequality can create dependence rather than conflict and where employers are generous, stable Paternalist relations (see Ackers 1996).
} 


\begin{abstract}
${ }^{5}$ Below I have simply replaced the word class with the employment relationship, in Thompson (1980:8): 'By the employment relationship I understand a historical phenomenon, unifying a number of disparate and seemingly unconnected events, both in the raw material of experience and in consciousness. I emphasize that it is a historical phenomenon. I do not see the employment relationship as a 'structure', nor even as a 'category', but as something which in fact happens (and can be shown to have happened) in human relationships...More than this, the notion of the employment relationship entails the notion of historical relationship. Like any other relationship, it is a fluency which evades analysis if we attempt to stop it dead at any given moment and anatomize its structure. The finest-meshed sociological net cannot give us a pure specimen of the employment relationship, any more than it can give us one of deference or of love. The relationship must always be embodied in real people and in a real context'.
\end{abstract}

\title{
References
}

Ackers, P. (2002) 'Reframing employment relations: the case for neo-pluralism, Industrial Relations Journal, 31(1), 2-19.

Ackers, P. (2004) 'Haunted by History: Industrial Relations Faces the Future' (review essay on Edwards, 2003), Organization Studies, 25(9):1623-1638.

Ackers, P. (2005a) 'Theorizing the Employment Relationship: Materialists and Institutionalists' (review essay including Blyton and Turnbull, 2004), British Journal of Industrial Relations, 43(3), September: 537-542.

Ackers, P. (2005b) 'Between the Devil and the Deep Blue Sea: Global IR History, the British Tradition, and the European Renaissance', Comparative Labor and Policy Journal, Fall: 93104.

Ackers P. (2011a) 'The Changing Systems of British Industrial Relations, 1954-1979: Hugh Clegg and the Warwick Sociological Turn', British Journal of Industrial Relations, 49(2): 306-330.

Ackers, P. (2011b) 'Finding the future in the past? The social philosophy of Oxford industrial relations pluralism', in Townsend, K. and Wilkinson, A. (eds) Research Handbook on the Future of Work and Employment Relations, Edward Elgar, Cheltenham, UK: 45-66.

Ackers, P. (2012) 'The Warwick School of Industrial Relations' (review of Colling and Terry 2010), Work, Employment and Society (forthcoming).

Allen, V. (1966) Militant Trade Unionism: A Re-Analysis of Industrial Action in an Inflationary Situation, London: Merlin.

Bain, G. (ed) (1983) Industrial Relations in Britain, Oxford: Blackwell.

Batstone, E. (1984) Working Order: Workplace Industrial Relations over Two Decades, Oxford: Blackwell.

Bhattacherjee, D. and Ackers, P. (2010) 'Introduction: employment relations in India - old narratives and new perspectives', Special Issue: Employment Relations in India, Industrial Relations Journal, 41(2): 104-121.

Blyton, P. and Turnbull, P. (1994, 1998, 2004) The Dynamics of Employee Relations, Basingstoke: Macmillan.

Budd, J.W. (2004) Employment with a Human Face: Balancing Efficiency, Equity and Voice, Ithaca, New York, Cornell University Press.

Clegg, H.A (1960) A new approach to Industrial Democracy, Oxford: Blackwell.

Clegg, H.A. (1963), Review of Trade Union Growth Structure and Policy, A Comparative

Study of the Cotton Unions by H.A. Turner (Allen and Unwin), Political Studies, 11: 226-7. Clegg, H.A. (1970) The System of British Industrial Relations, Oxford: Blackwell.

Clegg H.A, (1975) 'Pluralism in Industrial Relations', British Journal of Industrial Relations, 13(3): 309-16.

Clegg, H.A. (1979) The Changing System of British Industrial Relations, Oxford: Blackwell. Colling, T. and Terry, M. (2010) Industrial Relations: Theory and Practice, Third Edition, Wiley, Chichester, UK. 
Crouch, C, and Pizzorno, A (1978) The Resurgence of Class Conflict in Western Europe since 1968, Basingstoke: MacMillan.

Dunlop, J.T. (1958) Industrial Relations Systems, New York: Holt.

Edwards, P. (1995, 2003) ‘The Employment Relationship', in Edwards, P. (ed) Industrial

Relations, Oxford: Blackwell.

Edwards, P. (2010), in T. Colling and M. Terry (eds) Industrial Relations: Theory and

Practice, Third Edition, Wiley, Chichester, UK.

Edwards, P. and Sengupta, S. (2010), 'Industrial Relations and Economic Performance', in T.

Colling and M. Terry (eds) Industrial Relations: Theory and Practice, Third Edition, Wiley,

Chichester, UK.

Flanders, A. (1975) Management and Unions: The Theory and Reform of Industrial

Relations, London: Faber.

Flanders, A and Clegg, H.A. (eds) (1954) The System of Industrial Relations in Great Britain, Oxford: Blackwell.

Flanders (1964) The Fawley Productivity Agreements, London: Faber.

Fox, A. (1958) A History of the National Union of Boot and Shoe Operatives, 1874-1957,

Oxford: Blackwell.

Fox, A. (1966) 'Industrial Sociology and Industrial Relations', Royal Commission on Trade Unions and Employers' Associations, Research Papers 3, HMSO, London.

Fox, A. (1974) Beyond Contract: Work, Power and Trust Relations, London: Faber.

Fox, A. (1979) 'A Note on Industrial-Relations Pluralism', Sociology, 13: 105-109.

Fox, A. (1983) History and Heritage, London: Allen and Unwin.

Friedman (1993) 'The Social Responsibility of Business is to increase its profits' (original version 1970), in Chryssides, G.D. and Kaler, J.H. (eds), An Introduction to Business Ethics, Chapman and Hall, London.

Gabriel, Y. (1983) 'Collective Bargaining: A Critique of the Oxford School', Political Quarterly, 49 (3): 334-48.

Goldthorpe, J.H (1977) ‘Industrial Relations in Great Britain: A Critique of Reformism’ (original version 1974), in Clarke, T. and Clements, L. (eds), Trade Unions under Capitalism, Glasgow: Fontana.

Hakim, C. (2000) Work Life-Style Choices in the 21st Century, Oxford University Press. Hall, P.A. and Soskice, D. (eds) (2001) Varieties of Capitalism: The Institutional Foundations of Comparative Advantage, Oxford University Press.

Hayek, F.A. (1944) The Road to Serfdom, Routledge: London.

Heery, E (1993) 'Industrial Relations and the Customer', Industrial Relations Journal, 24(4): 284-95.

Hyman, R. (1975) Industrial Relations: A Marxist Introduction, MacMillan, Basingstoke. Hyman, R. (2001) Understanding European Unionism: Between Market, Class and Society, London, Sage.

Hyman, R. (2005) 'Striking a Balance? Means, Ends and Ambiguities', Symposium on John Budd, Employee Responsibilities and Rights Journal, 17 (2), June: 127-130.

Kahn, A.S and Ackers, P. (2004) 'Neo-pluralism as a theoretical framework for understanding HRM in sub-Saharan Africa', International Journal of HRM, 15(7): 13301353.

Kelly, J. (1988) Trade Unions and Socialist Politics, London: Verso.

Kelly, J. (1998) Rethinking Industrial Relations: Mobilization, Collectivism and Long Waves, Routledge, London.

Kelly, J. (2010) Ethical Socialism and the Trade Unions: Allan Flanders and British Industrial Relations Reform, Routledge, New York and Abingdon, UK.

Korczynski, M. (2002) Human Resource Management in the Service Sector, Basingstoke: Palgrave.

Nozick, R. (1974) Anarchy, State and Utopia, New York: Basic.

Parkin, F. (1974) 'Strategies of Social Closure in Class Formation', in Parkin, F. (ed) The Social Analysis of the Class Stucture, London: Tavistock: 1-18. 
Perkins, H. (1989) The Rise of Professional Society, London: Routledge.

Phillips, J. (2007) 'Industrial Relations, Historical Contingencies and Political Economy:

Britain in the 1960s and 1970s, Labour History Review, 72 (3), December: 215-234.

Ram, M. and Edwards, P. (2010), 'Industrial Relations in Small Firms', in T. Colling and M.

Terry (eds) Industrial Relations: Theory and Practice, Third Edition, Wiley, Chichester, UK. Reynaud, J-D. (1980) 'Industrial Relations and Political Systems: Some Reflections on the Crisis in Industrial Relations in Western Europe, British Journal of Industrial Relations, 18 (1): 1-13.

Sims, M. and Charlwood, A. (2010) 'Trade Unions: Power and Influence in a Changed Context', in Colling and Terry 2010: 125-146.

Sisson, K. (2009) 'Industrial Relations and the Employment Relationship', in Darlington, R. (ed) What's the Point of Industrial Relations: In Defence of Critical Social Science, Manchester: BUIRA.

Terry, M. (2010) 'Employee Representation', in Colling and Terry 2010: 275-297.

Thompson, K. (2004) Readings from Emile Durkheim, London: Routledge.

Thompson, E.P. (1976) 'On history, sociology and historical relevance', British Journal of Sociology, 27 (3), September: 381-402.

Thompson, E.P. (1980 edition) The Making of the English Working Class, London: Penguin. Turner, (1962) Trade Union Growth Structure and Policy, A Comparative Study of the Cotton Unions, London: Allen and Unwin.

Webb, S. and Webb, B. (1897) Industrial Democracy, London: Longmans.

Wood, S. and Elliot, R. (1977) A Critical Evaluation of Fox's Radicalisation of Industrial Relations Theory, Sociology, 11 (1), January: 105-125. 